\title{
Analisis Tingkat Kekritisan Lahan di DAS Tabunio Kabupaten Tanah Laut
}

\author{
Auliana, Ichsan Ridwan*, Nurlina
}

\author{
Program Studi Fisika Fakultas Matematika dan Ilmu Pengetahuan Alam \\ Universitas Lambung Mangkurat \\ *Email : ichsanridwan@unlam.ac.id
}

\begin{abstract}
Abstrak
Lahan termasuk sumber daya yang penting untuk memenuhi kebutuhan hidup, sehingga dalam pengelolaannya harus digunakan secara baik sesuai kemampuannya agar tidak menurunkan produktivitas lahan. Penggunaan lahan sering tidak diperhatikan kelestariannya terutama pada lahan-lahan yang mempunyai keterbatasan fisik maupun kimia. Apabila kondisi ini berlangsung terus menerus dikhawatirkan akan terjadi lahan kritis yang mengakibatkan penurunan kesuburan tanah dan produktivitas tanah. Lahan kritis didefinisikan sebagai lahan yang mengalami proses kerusakan fisik, kimia dan biologi karena tidak sesuai penggunaan dan kemampuannya, yang akhirnya membahayakan fungsi hidrologis, orologis, produksi pertanian, permukiman, dan kehidupan sosial ekonomi dan lingkungan. Tujuan penelitian ini adalah menganalisis tingkat kekritisan lahan di Daerah Aliran Sungai (DAS) Tabunio dan menentukan daerah lahan kritis di DAS Tabunio. Metode yang digunakan dalam analisis spasial lahan kritis adalah metode skoring. Analisis spasial lahan kritis dilakukan dengan menumpangsusunkan (Overlay) beberapa parameter penentu lahan kritis seperti Peta Kemiringan Lereng, Peta Penutupan Tajuk, Peta Tingkat Bahaya Erosi dan Peta Manajemen Lahan untuk memperoleh total skor dari masing-masing unit lahan dan hasil berupa peta lahan kritis dengan menggunakan Sistem Informasi Geografis (SIG). Hasil analisis menunjukkan DAS Tabunio memiliki lima kategori tingkat kekritisan lahan yaitu lahan yang termasuk kriteria Sangat Kritis seluas 71,68 ha atau 0,11\%, Kritis seluas 1.320,60 ha atau 2,11\%, Agak Kritis seluas 8.090,73 atau 12,93\%, Potensial Kritis seluas 30.657,21 ha atau 49,01\% dan Tidak Kritis seluas $22.418,34$ ha atau 35,84\% sedangkan luas Lahan Kritis di DAS Tabunio yaitu seluas 1.392,26 ha atau $2,22 \%$ dimana hasil tersebut penjumlahan dari tiga kawasan yaitu kawasan hutan lindung seluas 836,08 ha, kawasan budidaya pertanian seluas 355,33 ha dan kawasan hutan lindung di luar kawasan hutan seluas 200,85 ha.
\end{abstract}

Kata Kunci: lahan kritis, overlay, SIG, skoring, tingkat kekritisan lahan

\section{Latar Belakang}

Daerah Aliran Sungai (DAS) Tabunio terletak di Kabupaten Tanah Laut Kalimantan Selatan dengan luas DAS 62.558,56 ha. Pembukaan lahan yang tinggi baik untuk sektor pertambangan maupun perkebunan kelapa sawit membuat tiga wilayah DAS di Kalimanatan Selatan yakni DAS Batulicin, DAS Satui dan DAS Tabunio sangat rentan banjir sehingga sangat jelas berdampak besar terhadap meningkatnya kerawanan banjir, ditambah dengan banyaknya kebakaran lahan sepanjang musim kemarau sehingga proses infiltrasi air hujan tidak lagi berjalan secara baik.

Informasi tentang luas dan tingkat kekritisan lahan dapat diperoleh dengan cara memetakan lahan kritis sebagai salah satu upaya rehabilitasi hutan dan lahan. Ini sesuai dengan tujuan penelitian ini adalah menganalisis tingkat kekritisan lahan dan menentukan daerah lahan kritis di DAS Tabunio. Salah satu cara memetakan lahan kritis adalah dengan menggunakan Sistem Informasi Geografis (SIG). Lahan termasuk sumber daya yang penting untuk memenuhi kebutuhan hidup sehingga dalam pengelolaannya harus digunakan secara baik sesuai kemampuannya agar tidak menurunkan produktivitas lahan. Dalam penggunaan lahan sering tidak memperhatikan kelestariannya terutama pada lahan-lahan yang mempunyai keterbatasan, baik keterbatasan fisik maupun kimia. Apabila kondisi ini berlangsung terus menerus dikhawatirkan akan terjadi lahan kritis yang mengakibatkan penurunan kesuburan tanah dan produktivitas tanah. Berdasarkan kajian yang telah dilakukan Puslittanak, Lahan kritis didefinisikan sebagai lahan yang mengalami proses kerusakan fisik, kimia, dan biologi karena tidak sesuai pengguna dan kemampuannya, yang akhirnya membahayakan fungsi hidrologis, orologis, produksi pertanian, permukiman dan kehidupan sosial ekonomi dan lingkungan [1].

\subsection{Daerah Aliran Sungai}

DAS adalah suatu wilayah daratan yang secara topografi dibatasi oleh punggungpunggung gunung yang menampung dan menyimpan air hujan untuk kemudian menyalurkan ke laut melalui sungai utama. Dalam hubungannya dengan sistem hidrologi, DAS mempunyai karakteristik yang spesifik serta berkaitan erat dengan unsur utamanya seperti jenis tanah, tataguna lahan, topografi, 
kemiringan dan panjang lereng. Curah hujan, jenis tanah, kemiringan lereng, vegetasi dan aktivitas kehidupan manusia mempunyai peranan penting untuk berlangsungnya proses erosi-sedimentasi [2].

\subsection{Lahan Kritis}

Poerwowidodo (1990) memandang lahan kritis sebagai keadaan lahan yang terbuka sebagai akibat adanya erosi yang berat dan menyebabkan produktivitas pada lahan tersebut menjadi rendah. Lahan kritis juga digambarkan sebagai suatu keadaan lahan yang terbuka atau tertutupi semak belukar, sebagai akibat dari solum tanah yang tipis dengan batuan bermunculan di permukaan tanah akibat tererosi berat dan produktivitasnya rendah [3]. Ciri utama lahan kritis adalah gundul, terkesan gersang dan bahkan muncul batu-batuan di permukaan tanah dan pada umumnya terletak di wilayah dengan topografi lahan berbukit atau berlereng curam $[4,5]$.

Parameter penentu lahan kritis berdasarkan Permenhut Nomor P.32/Menhut II/2009, meliputi [6]:
a. Penutupan Lahan
b. Kemiringan Lereng
c. Tingkat bahaya erosi
d. Manajemen Lahan

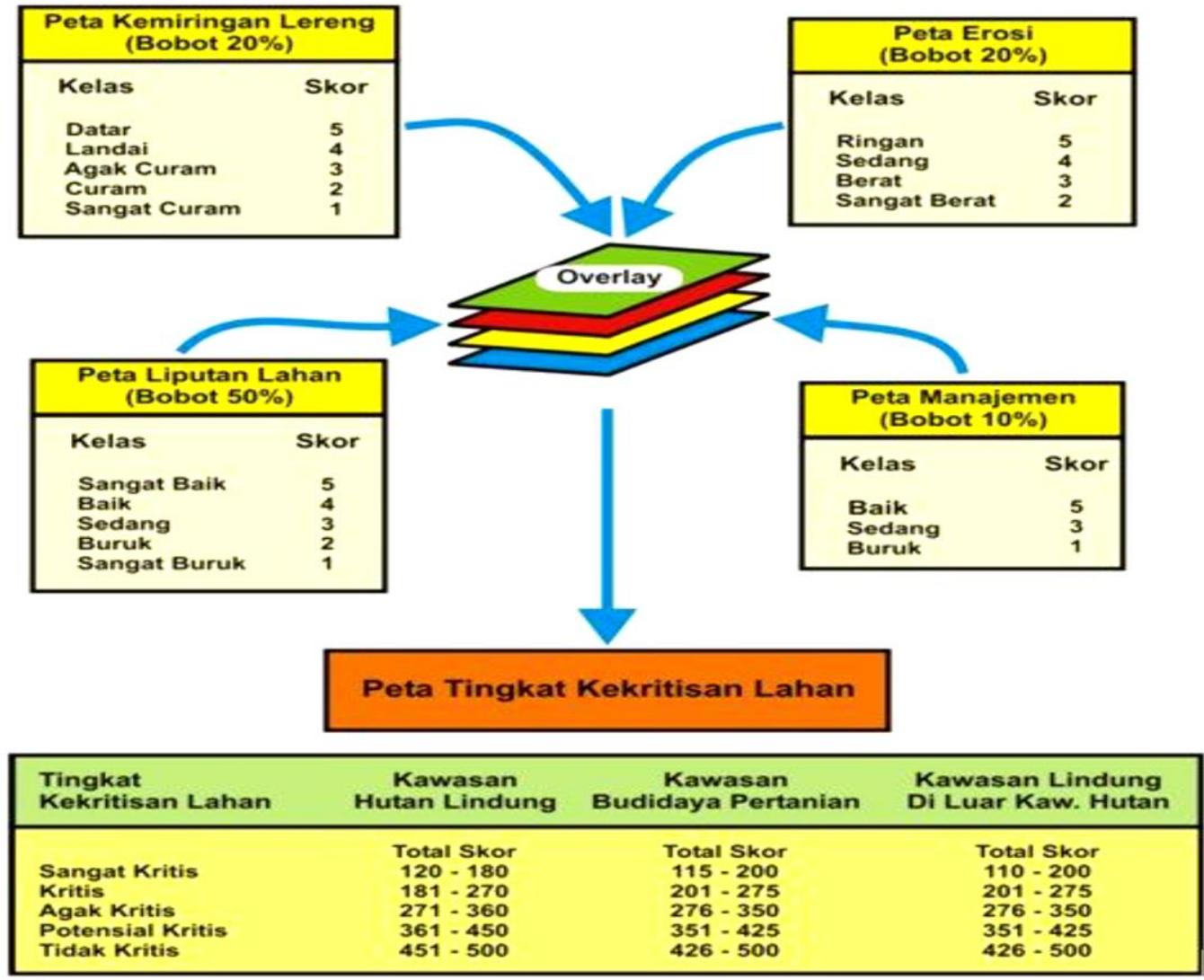

Gambar 1 Diagram Alir Penentuan Tingkat Lahan Kritis [6]

\subsection{Sistem Informasi Geografis}

Secara spesifik Arronof mendefinisikan SIG sebagai suatu sistem berbasis komputer yang mempunyai kemampuan untuk menangani data yang bereferensi geografi yaitu pemasukan data, manajemen data (penyimpanan data dan pemanggilan data), memanipulasi data analisis, memberi uraian serta output (pengembangan produk dan percetakan) [7]. Hasilnya akhirnya dapat dijadikan acuan untuk pengambilan keputusan. SIG bisa menjadi alat yang sangat penting pada keputusan untuk pembangunan berkelanjutan karena SIG memberi informasi pada pengambil keputusan untuk analisis dan penerapan database keruangan.
Overlay merupakan prosedur penting dalam analisis SIG. Overlay adalah kemampuan untuk menempatkan grafis satu peta di atas grafis peta yang lain dan menampilkan hasilnya di layar komputer atau pada plot. Secara singkatnya, overlay menampilkan suatu peta digital pada peta digital yang lain beserta atribut-atributnya dan menghasilkan peta gabungan keduanya yang memiliki informasi atribut dari kedua peta tersebut. Overlay peta dilakukan minimal dengan dua jenis peta yang berbeda. Fasilitas overlay disini menggunakan Dissolve, Union, Intersect, dan Clip [8]. 


\section{Metodologi}

Penelitian ini dilakukan di DAS Tabunio Kabupaten Tanah Laut Kalimantan Selatan dengan luas DAS 62.558,56 ha. Parameter kemiringan lereng dinilai berdasarkan persentase kelerengan, begitu juga dengan penutupan lahan dinilai berdasarkan persentase penutupan tajuk pohon. Sedangkan, Tingkat bahaya erosi dinilai berdasarkan kerusakan/ hilangnya lapisan tanah, baik untuk tanah dalam maupun dangkal dan manajemen lahan dinilai berdasarkan kelengkapan ada atau tidaknya tata batas kawasan, pengamanan dan adanya penyuluhan. Penilaian lahan kritis ini berupa lahan-lahan yang ada kaitannya dengan kegiatan reboisasi dan penghijauan, yaitu fungsi kawasan hutan lindung, kawasan budidaya pertanian dan kawasan hutan lindung di luar kawasan.

Alat dan bahan yang digunakan dalam penelitan ini adalah sebagai berikut:

1. Software ArcGIS 10.1

2. Komputer dengan spesifikasi minimal: RAM 1 GB dan Hard Disk 40 GB

3. Batas DAS Tabunio

4. Data Elevation Model (DEM) The Shuttle Radar Topography Mission (SRTM) resolusi $30 \mathrm{~m}$

5. Peta Tutupan Lahan

6. Peta Tingkat Bahaya Erosi

7. Peta Manajemen Lahan

8. Peta Batas Fungsi Kawasan DAS Tabunio
Analisis spasial lahan kritis dilakukan dengan Overlay beberapa parameter penentu lahan kritis seperti Peta Kemiringan Lereng, Peta Penutupan Tajuk, Peta Tingkat Bahaya Erosi dan Peta Manajemen Lahan. Metode yang digunakan dalam analisis spasial lahan kritis adalah metode skoring. Pada unit analisis hasil tumpang susun data spasial skor tersebut kemudian dijumlahkan. Hasil penjumlahan skor selanjutnya diklasifikasi untuk menentukan tingkat lahan kritis. Berdasarkan diagram penentuan tingkat lahan kritis seperti ditunjukkan pada Gambar 1, maka dapat dituliskan persamaan masing-masing parameter lahan kritis sebagai berikut:

$$
\begin{gathered}
\text { TLK KHL = } 0,5(\mathrm{PL})+0,2(\mathrm{KL})+0,2(\mathrm{TBE})+ \\
0,1(\mathrm{MLH}) \\
\begin{aligned}
\text { TLK KHL }= & 0,3(\mathrm{KL})+0,3(\mathrm{TBE})+0,4(\mathrm{MLH}) \\
\text { TLK KLNKH }= & 0,5(\mathrm{PL})+0,1(\mathrm{KL})+0,1(\mathrm{TBE})+ \\
& 0,3(\mathrm{MLH})
\end{aligned}
\end{gathered}
$$

Keterangan:

TLK : Tingkat Lahan Kritis

KHL : Kawasan Hutan Lindung

KBP : Kawasan Budidaya Pertanian

PL : Penutupan Lahan

KL : Kemiringan Lereng

TBE : Tingkat Bahaya Erosi

MLH : Manajeman Lahan

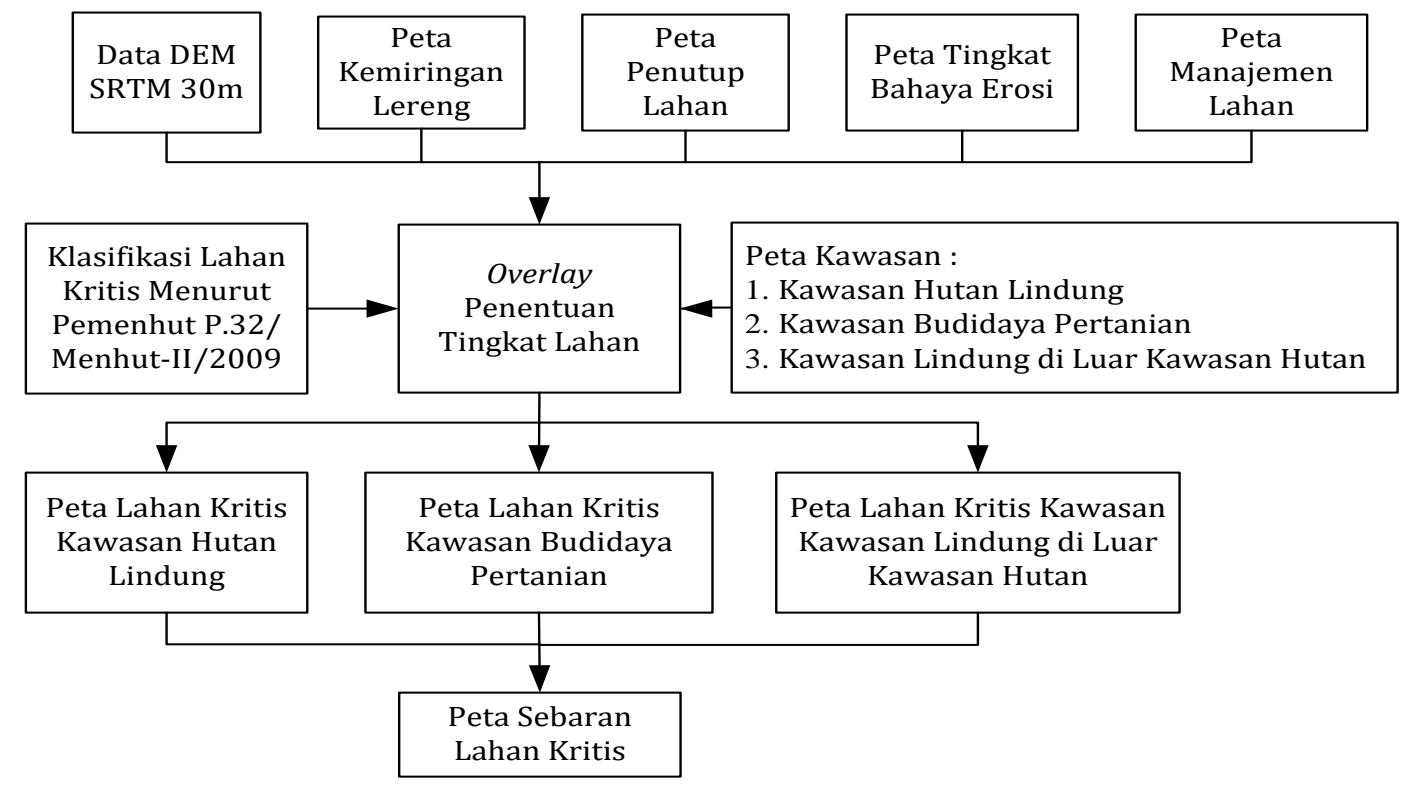

Gambar 1. Diagram Alur Penelitian

\section{Hasil dan Pembahasan}

\subsection{Analisis Kekritisan Lahan}

Kawasan Hutan Lindung

Kawasan hutan lindung di DAS Tabunio memiliki luas 9.548,47 ha atau sekitar 15,26\% dari luas DAS Tabunio yaitu seluas $62.558,56$ ha. Parameter yang digunakan untuk menentukan peta kawasan hutan lindung adalah kemiringan lereng, penutupan lahan, tingkat bahaya erosi, dan manajemen lahan. Tabel 1 dan Tabel 2 menunjukkan tingkat kekritisan lahan kawasan hutan lindung dan budidaya pertanian. 
Tabel 1. Tingkat Kekritisan Lahan Kawasan Hutan Lindung

\begin{tabular}{crr}
\hline $\begin{array}{c}\text { Tingkat Kekritisan } \\
\text { Lahan (ha) }\end{array}$ & \multicolumn{1}{c}{$\begin{array}{c}\text { Luas } \\
\text { (ha) }\end{array}$} & \multicolumn{1}{c}{$\begin{array}{c}\text { Luas } \\
\text { (\%) }\end{array}$} \\
\hline Sangat Kritis & 46,81 & 0,49 \\
Kritis & 789,27 & 8,27 \\
Agak Kritis & $4.451,43$ & 46,62 \\
Potensial Kritis & $4.116,80$ & 43,11 \\
Tidak Kritis & 144,16 & 1,51 \\
\hline Total & $9.548,47$ & 100,00 \\
\hline
\end{tabular}

Berdasarkan Tabel 1 dapat dilihat bahwa pada Kawasan Hutan Lindung terdapat 836,08 ha yang masuk kategori lahan kritis. Hal tersebut dapat mengganggu fungsi Hutan Lindung sebagai daerah resapan air dan penyedia jasa ekosistim oksigen dan cadangan karbon.

\section{Kawasan Budidaya Pertanian}

Kawasan budidaya pertanian memiliki luas $51.103,90$ ha atau sekitar $81,69 \%$ dari luas DAS Tabunio. Parameter yang digunakan untuk menentukan peta kawasan budidaya pertanian adalah kemiringan lereng, tingkat bahaya erosi, dan manajemen lahan ditunjukkan pada Tabel 2.

Tabel 2. Tingkat Kekritisan Lahan Kawasan Budidaya Pertanian

\begin{tabular}{crr}
\hline $\begin{array}{c}\text { Tingkat Kekritisan } \\
\text { Lahan (ha) }\end{array}$ & \multicolumn{1}{c}{$\begin{array}{c}\text { Luas } \\
\text { (ha) }\end{array}$} & \multicolumn{1}{c}{$\begin{array}{c}\text { Luas } \\
(\%)\end{array}$} \\
\hline Sangat Kritis & 15,39 & 0,03 \\
Kritis & 339,94 & 0,67 \\
Agak Kritis & $3.236,56$ & 6,33 \\
Potensial Kritis & $25.439,75$ & 49,78 \\
Tidak Kritis & $22.072,26$ & 43,19 \\
\hline Total & $51.103,90$ & 100,00 \\
\hline Berdasarkan hasil yang diperoleh pada Tabel
\end{tabular}

2, umumnya Kawasan Budidaya Pertanian berada pada kategori Tidak Kritis dan Potensial Kritis. Namun, masih terdapat 355,33 ha $(0,7 \%)$ yang masih dalam ketegori lahan kritis.

\section{Kawasan Lindung di Luar Kawasan Hutan}

Kawasan lindung di luar kawasan hutan di DAS Tabunio memiliki luas 1.906,19 ha atau sekitar 3,04\% dari luas DAS Tabunio. Parameter yang digunakan untuk menentukan tingkat kekritisan lahan pada peta kawasan Lindung di Luar Kawasan Hutan adalah kemiringan lereng, penutupan lahan, tingkat bahaya erosi, dan manajemen lahan. Tabel 3 menunjukkan tingkat kekritisan lahan kawasan Lindung di Luar Kawasan Hutan.
Tabel 3. Tingkat Kekritisan Lahan Kawasan Lindung di Luar Kawasan Hutan

\begin{tabular}{crr}
\hline $\begin{array}{c}\text { Tingkat Kekritisan } \\
\text { Lahan (ha) }\end{array}$ & \multicolumn{1}{c}{$\begin{array}{c}\text { Luas } \\
\text { (ha) }\end{array}$} & \multicolumn{1}{c}{$\begin{array}{c}\text { Luas } \\
\text { (\%) }\end{array}$} \\
\hline Sangat Kritis & 9,46 & 0,50 \\
Kritis & 191,39 & 10,04 \\
Agak Kritis & 402,78 & 21,13 \\
Potensial Kritis & $1.100,66$ & 57,74 \\
Tidak Kritis & 201,90 & 10,59 \\
\hline Total & $1.906,19$ & 100,00 \\
\hline
\end{tabular}

Hasil analsis tingkat kekritisan lahan kawasan lindung di luar kawasan hutan seperti pada Tabel 3 , memperlihatkan bahwa masih ada 200,85 ha $(10,54 \%)$ yang masuk kategori lahan kritis. Hal ini disebabkan karena daerah sempadan sungai di bagian hulu sungai Tabunio yang merupakan kawasan lindung terdapat aktivitas tambang emas masyarakat.

\subsection{Lahan Kritis}

Tiga peta kawasan tersebut masing-masing dianalisis tingkat kekritisan dan daerahnya. Dari hasil analisis tersebut maka diperoleh tingkat kekritisan lahan secara keseluruhan di DAS Tabunio seluas 1.392,26 ha atau 2,22\% dari luas DAS Tabunio. Hasil tersebut merupakan penjumlahan dari kriteria Kritis dan Sangat Kritis yang masing-masing diperoleh dari tiga kawasan yang ditunjukkan pada Tabel 4 dan peta sebarannya pada Lampiran 1.

Tabel 4. Luas Tingkat Kekritisan Lahan di DAS Tabunio tahun 2016

\begin{tabular}{crr}
$\begin{array}{c}\text { Tingkat Kekritisan } \\
\text { Lahan (ha) }\end{array}$ & \multicolumn{1}{c}{$\begin{array}{c}\text { Luas } \\
\text { (ha) }\end{array}$} & \multicolumn{1}{c}{$\begin{array}{c}\text { Luas } \\
\text { (\%) }\end{array}$} \\
\hline Sangat Kritis & 71,68 & 0,11 \\
Kritis & $1.320,60$ & 2,11 \\
Agak Kritis & $8.090,73$ & 12,93 \\
Potensial Kritis & $30.657,21$ & 49,00 \\
Tidak Kritis & $22.418,34$ & 35,84 \\
\hline Total & $62.558,56$ & 100,00 \\
\hline
\end{tabular}

Tabel 5. Luas Lahan Kritis DAS Tabunio 2016

\begin{tabular}{|c|c|c|c|}
\hline \multirow{2}{*}{$\begin{array}{c}\text { Kawasan DAS } \\
\text { Tabunio }\end{array}$} & \multicolumn{2}{|c|}{$\begin{array}{c}\text { Tingkat Lahan } \\
\text { Kritis (ha) }\end{array}$} & \multirow{2}{*}{$\begin{array}{l}\text { Total } \\
\text { (ha) }\end{array}$} \\
\hline & $\begin{array}{l}\text { Sangat } \\
\text { Kritis }\end{array}$ & Kritis & \\
\hline Hutan Lindung & 46,81 & 789,27 & 836,08 \\
\hline Budidaya Pertanian & 15,39 & 339,94 & 355,33 \\
\hline $\begin{array}{l}\text { Hutan Lindung di } \\
\text { Luar Kawasan } \\
\text { Hutan }\end{array}$ & 9,46 & 191,39 & 200,85 \\
\hline Total & 71,66 & $1.320,60$ & $1.392,26$ \\
\hline
\end{tabular}




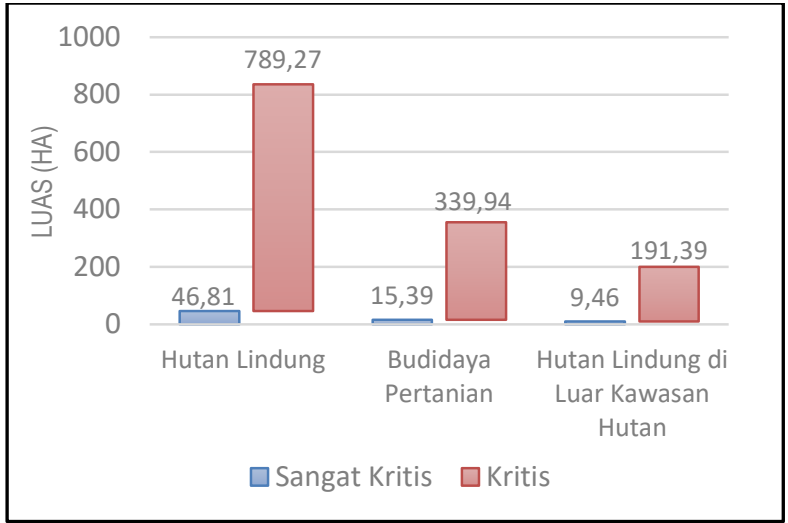

Gambar 3. Grafik Luas Lahan Kritis di DAS Tabunio Tahun 2016

Berdasarkan hasil yang diperlihatkan pada Tabel 5 dan Gambar 3, terlihat bahwa Lahan Kritis di DAS Tabunio dominan berada pada area Hutan Lindung. Pengelolaan Kawasan Hutan Lindung merupakan tanggung jawab Kementrian Lingkungan Hidup dan Kehutanan (KLHK) untuk menjaga fungsi Hutan Lindung sebagai daerah resapan air dan penyedia jasa lingkungan lainnya. Berdasarkan peta sebaran pada Lampiran 2, terlihat bahwa area lahan kritis berada pada bagian hulu DAS dengan kelerengan terjal dan sepanjang aliran sungai Tabunio.

Tabel 6. Luas Tingkat Kekritisan Lahan di DAS Tabunio tahun 2013

\begin{tabular}{crr}
$\begin{array}{c}\text { Tingkat Kekritisan } \\
\text { Lahan (ha) }\end{array}$ & \multicolumn{1}{c}{$\begin{array}{c}\text { Luas } \\
\text { (ha) }\end{array}$} & \multicolumn{1}{c}{$\begin{array}{c}\text { Luas } \\
(\%)\end{array}$} \\
\hline Sangat Kritis & $2.460,07$ & 3,93 \\
Kritis & $16.649,82$ & 26,61 \\
Agak Kritis & $29.521,72$ & 47,19 \\
Potensial Kritis & $13.926,95$ & 22,26 \\
Tidak Kritis & $22.418,34$ & 35,84 \\
\hline Total & $62.558,56$ & 100,00 \\
\hline
\end{tabular}

Sumber: BPDAS Barito [9].

Perbandingan luas lahan kritis pada tahun 2013 (Tabel 6) dan 2016 (Tabel 4) menunjukkan perbedaan yang sangat tinggi. Semula lahan kritis seluas $19.109,89$ ha atau $30,54 \%$ menjadi $1.392,26$ ha atau $2,22 \%$ dan lahan yang termasuk kriteria tidak kritis dari tidak ada atau $0 \%$ menjadi $22.418,34$ ha atau $35,84 \%$. Upaya rehabilitasi hutan dan lahan di DAS Tabunio telah dilakukan dengan baik seperti yang terlihat perubahan tiga tahun terakhir. Daerah dengan kategori Sangat Kritis dan Kritis berkurang karena adanya perubahan penggunaan lahan menjadi perkebunan, seperti perkebunan kelapa sawit dan karet. Hal ini mengindikasikan lahan yang semula dengan vegetasi hutan yang sudah sangat sedikit sudah menjadi cukup baik.

\section{Kesimpulan}

Kesimpulan yang dihasilkan dari penelitian ini adalah sebagai berikut.

1. DAS Tabunio memiliki lima kategori tingkat kekritisan lahan yaitu lahan yang termasuk kriteria Sangat Kritis seluas 71,68 ha atau $0,11 \%$, Kritis seluas $1.320,60$ ha atau $2,11 \%$, Agak Kritis seluas 8.090,73 atau 12,93\%, Potensial Kritis seluas $30.657,21$ ha atau 49,01\% dan Tidak Kritis seluas 22.418,34 ha atau $35,84 \%$.

2. Luas lahan kritis di DAS Tabunio yaitu seluas $1.392,26$ ha atau $2,22 \%$ dari luas DAS Tabunio, dimana hasil tersebut penjumlahan dari tiga kawasan yaitu kawasan hutan lindung seluas 836,08 ha, kawasan budidaya pertanian seluas 355,33 ha dan kawasan hutan lindung di luar kawasan hutan seluas 200,85 ha.

3. Upaya rehabilitasi hutan dan lahan di DAS Tabunio telah berjalan dengan baik seperti yang terlihat perubahan tiga tahun terakhir. Daerah dengan kategori Sangat Kritis dan Kritis berkurang karena adanya perubahan lahan kritis menjadi perkebunan.

\section{Daftar Pustaka}

[1] Puslittanak, Panduan Pemetaan Lahan Kritis. Pusat Penelitian Tanah dan Agroklimat. Bogor. 1997.

[2] Asdak, S., Hidrologi dan pengelolaan Daerah Aliran Sungai, cetakan ketiga, Gadjah Mada University Press, Yogyakarta. 2014.

[3] Poerwowidodo, Gatra Tanah dalam Pembangunan Hutan tanaman di Indonesia. Rajawali Press. Bogor. 1990.

[4] Prawira, A.Y., Wikantika, K. and Hadi, F., Analisis Lahan Kritis di Kota Bandung Utara Menggunakan Open Source GRASS. Prosiding PIT MAPIN XIV. Bogor. 2005.

[5] Herdiana, D., Identifikasi Lahan Kritis dalam Kaitannya dengan Penataan Ruang dan Kegiatan Rehabilitasi Lahan di Kabupaten Sumedang. Tesis.Sekolah Pasca Sarjana. Institut Pertanian Bogor. Bogor. 2008.

[6] Peraturan Direktur Jenderal Bina Pengelolaan Daerah Aliran Sungai Dan Perhutanan Sosial, Petunjuk Teknis Penyusunan Data Spasial Lahan Kritis. Kemenhut, Jakarta. 2013.

[7] Arronof, Geographic Information System : A Management Perspective WDL. Publication Otawa. Canada. 1989.

[8] Prahasta, E., Konsep-konsep Dasar Sistem Informasi Geografis. Informatika. Bandung. 2014.

[9] BPDAS Barito, Updating Data Spasial Lahan Kritis Wilayah Kerja Balai Pengelolaan DAS Barito Tahun 2013. Banjarbaru. 2013 
POSITRON, Vol. VII, No. 2 (2017), Hal. 54 - 59

ISSN: 2301-4970 (print)

ISSN: 2549-936X (online)

LAMPIRAN

1. Peta Tingkat Kekritisan Lahan DAS Tabunio 2016

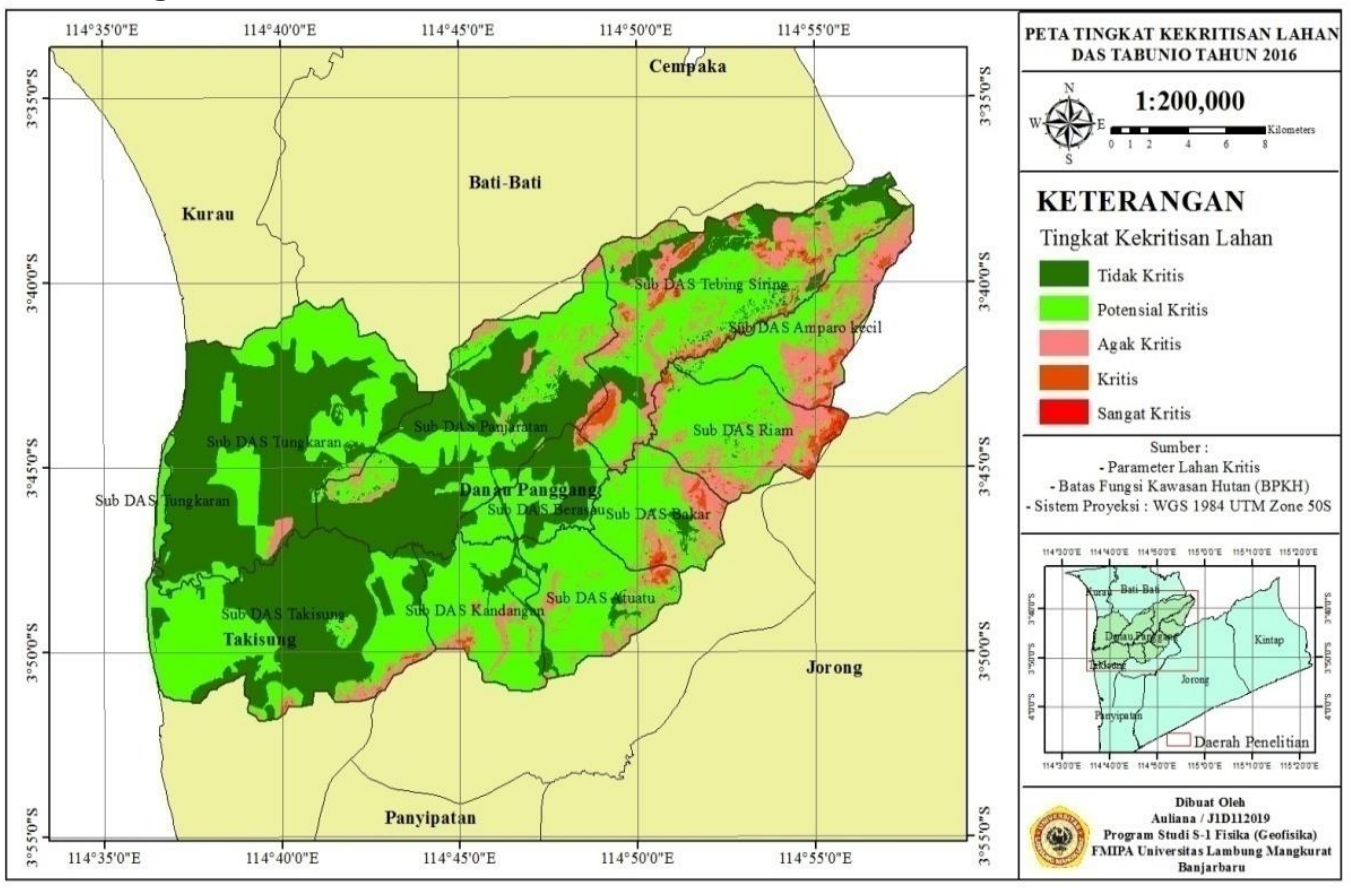

2. Peta Lahan Kritis DAS Tabunio 2016.

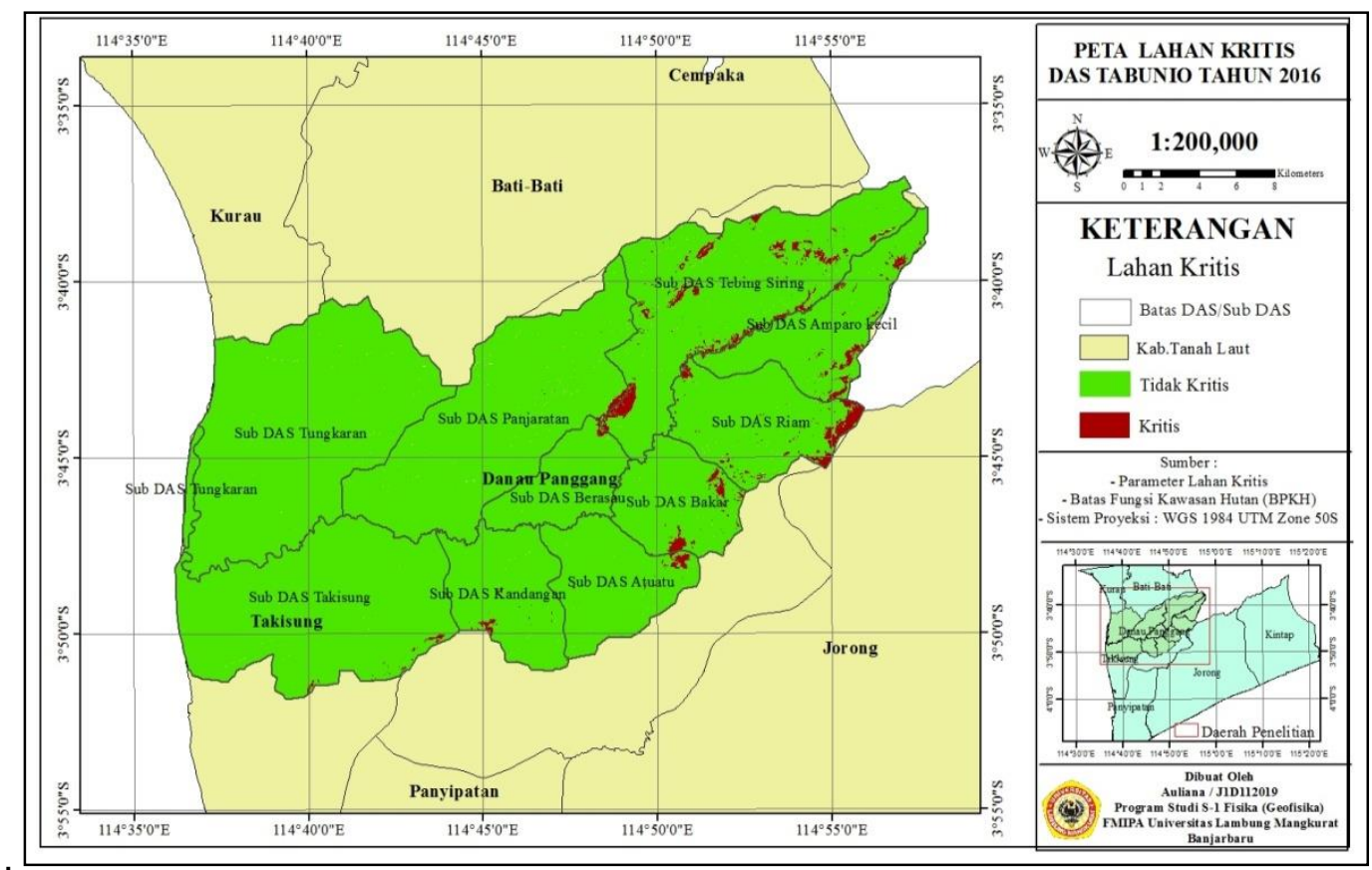

